\title{
Desulfohalobium utahense sp. nov., a moderately halophilic, sulfate-reducing bacterium isolated from Great Salt Lake
}

\author{
Trine Fredlund Jakobsen, Kasper Urup Kjeldsen and Kjeld Ingvorsen
}

Correspondence

Kjeld Ingvorsen

kjeld.ingvorsen@biology.au.dk
Department of Microbiology, University of Aarhus, Ny Munkegade Building 1540, DK-8000 Aarhus C, Denmark
A novel moderately halophilic, sulfate-reducing bacterium, strain $\mathrm{EtOH}^{\top}$, was isolated from anoxic hypersaline (270 $\mathrm{g} \mathrm{NaCl}^{-1}$ ) sediment of the northern arm of the Great Salt Lake, Utah, USA. Cells of strain $\mathrm{EtOH}^{\top}$ were oval to rod-shaped, non-motile, non-sporulating and stained Gram-negative. The strain required sodium and magnesium ions for growth and grew at salinities of up to $240 \mathrm{~g} \mathrm{NaCl} \mathrm{I}^{-1}$ and $121 \mathrm{~g} \mathrm{MgCl}_{2} \cdot 6 \mathrm{H}_{2} \mathrm{O} \mathrm{I}^{-1}$. The optimum $\mathrm{NaCl}$ concentration was 80-100 $\mathrm{g} \mathrm{I}^{-1}$. Strain $\mathrm{EtOH} 3^{\top}$ grew at temperatures ranging from 15 to $44^{\circ} \mathrm{C}$ (optimum $37^{\circ} \mathrm{C}$ ). The $\mathrm{pH}$ range for growth was $6 \cdot 5-8 \cdot 3$ (optimum around $\mathrm{pH} 6 \cdot 8$ ). Only sulfate and thiosulfate served as electron acceptors for a broad range of electron donors including various short-chain fatty acids and primary $\left(\mathrm{C}_{1-5}\right)$ alcohols, amino acids, $\mathrm{H}_{2}$ /acetate and $\mathrm{H}_{2}$ /yeast extract. The $\mathrm{G}+\mathrm{C}$ content of the genomic DNA was $51.4 \mathrm{~mol} \%$. Phylogenetic analysis of $d s r A B$ [genes encoding the major subunits of dissimilatory (bi)sulfite reductase] and 16S rRNA gene sequence data placed strain $\mathrm{EtOH}^{\top}$ within the deltaproteobacterial family Desulfohalobiaceae. Strain $\mathrm{EtOH}^{\top}$ shared 76 and $91 \% d s r A B$ and $16 \mathrm{~S}$ rRNA gene sequence similarity, respectively, with the type strain of the phylogenetically most closely related species with a validly published name, Desulfohalobium retbaense DSM $5692^{\top}$. High $16 \mathrm{~S}$ rRNA gene sequence similarity ( $\left.\sim 97 \%\right)$ was shared with the recently described strain 'Desulfovermiculus halophilus' VKM B-2364. Strain $\mathrm{EtOH}^{\top}$, however, clearly differed from this strain in both genomic $\mathrm{G}+\mathrm{C}$ content and in several of its phenotypic properties. On the basis of phenotypic and genotypic characteristics, the novel species Desulfohalobium utahense sp. nov. is proposed, with strain $\mathrm{EtOH}^{\top}\left(=\mathrm{VKM} \mathrm{B}^{-238} 4^{\top}=\mathrm{DSM}\right.$ $17720^{\top}$ ) as the type strain.
The northern arm of Great Salt Lake (Utah, USA) is a thalassohaline hypersaline environment with salinities of $\geqslant 270 \mathrm{~g} \mathrm{NaCll}^{-1}$. Despite the extreme salinity, the sediment from this part of the lake was recently shown to harbour active populations of sulfate-reducing micro-organisms (Brandt et al., 2001), although so far the identity of these sulfate reducers has remained unknown. In recent years, growing interest in micro-organisms from hypersaline environments has led to the isolation of a limited number of halophilic sulfate-reducing bacteria (SRB). However, most of these SRB are only weakly halophilic and would hardly be able to proliferate at the elevated salinities in the northern arm of the Great Salt Lake. Thus, members of only

\section{Abbreviation: SRB, sulfate-reducing bacteria.}

The GenBank/EMBL/DDBJ accession number for the $d s r A B$ and the 16S rRNA gene sequences of strain $\mathrm{EtOH}^{\top}$ are DO386236 and DQ067421, respectively.

A transmission electron micrograph of a cell of strain $\mathrm{EtOH}^{\top}$ is available as supplementary material in IJSEM Online. five described SRB species are able to grow in vitro at salinities exceeding $200 \mathrm{~g} \mathrm{NaCll}^{-1}$, namely Desulfohalobium retbaense DSM 5692 ${ }^{\mathrm{T}}$, which grows at salinities up to $240 \mathrm{~g} \mathrm{l}^{-1}$ (Ollivier et al., 1991), 'Desulfovermiculus halophilus' VKM B-2364 (Belyakova et al., 2006), growing at salinities up to $230 \mathrm{~g} \mathrm{l}^{-1}$, and three members of the genus Desulfovibrio, growing at salinities up to 217-225 $\mathrm{g} \mathrm{l}^{-1}$, 'Desulfovibrio cavernae' B1T (Sass \& Cypionka, 2004), Desulfovibrio indonesiensis strains B1M and H3M (Sass \& Cypionka, 2004) and Desulfovibrio oxyclinae DSM $11498^{\mathrm{T}}$ (Krekeler et al., 1997).

In the course of a survey of the diversity of SRB inhabiting the sediment of the northern arm of the Great Salt Lake, several novel sulfate-reducing strains were isolated. One strain, designated $\mathrm{EtOH}_{3}{ }^{\mathrm{T}}$, was characterized further and assigned to the deltaproteobacterial genus Desulfohalobium as the type strain of a novel species. Strain $\mathrm{EtOH} 3^{\mathrm{T}}$ and Desulfohalobium retbaense represent the most halophilic SRB described to date and together constitute the only recognized members of the genus Desulfohalobium, which is 
the type genus of the family Desulfohalobiaceae (Kuever et al., 2005). In addition to these taxa, other species affiliated with this family include Desulfonatronovibrio hydrogenovorans (Zhilina et al., 1997), Desulfothermus naphthae (Kuever et al., 2006), Desulfonauticus submarinus (Audiffrin et al., 2003) and 'Desulfovermiculus halophilus' (Belyakova et al., 2006).

Strain $\mathrm{EtOH}^{\mathrm{T}}$ was isolated from an anoxic hypersaline $\left(270 \mathrm{~g} \mathrm{NaCl} \mathrm{l}^{-1}\right)$ sediment sample, obtained from Station 27 (Brandt et al., 2001). Strain EtOH $3^{\mathrm{T}}$ was enriched, isolated and routinely cultivated in an anoxic basal medium (BM) consisting of $\left(1^{-1}\right.$ Milli-Q water): $\mathrm{NaCl}, 100 \mathrm{~g}$; $\mathrm{MgSO}_{4} .7 \mathrm{H}_{2} \mathrm{O}, 10 \mathrm{~g} ; \mathrm{KCl}, 6.0 \mathrm{~g} ; \mathrm{CaCl}_{2} .2 \mathrm{H}_{2} \mathrm{O}, 0.4 \mathrm{~g}$; $\mathrm{NH}_{4} \mathrm{Cl}, 1.0 \mathrm{~g} ; \mathrm{KH}_{2} \mathrm{PO}_{4}, 0.1 \mathrm{~g}$; yeast extract, $0.5 \mathrm{~g}$; trace element solution, $1.0 \mathrm{ml}$ (Widdel \& Bak, 1992); $20 \mathrm{~g} \mathrm{l}^{-1}$ resazurin solution, $50 \mu \mathrm{l}$; selenite tungstate solution, $1 \cdot 0 \mathrm{ml}$ (Widdel \& Bak, 1992). The medium was prepared as described by Brandt \& Ingvorsen (1997). $\mathrm{NaHCO}_{3}(30 \mathrm{mM}$ final concentration) was used as the buffer and the $\mathrm{pH}$ was $7 \cdot 0-7 \cdot 2$. Unless otherwise noted, all incubations were carried out at $30{ }^{\circ} \mathrm{C}$ in the dark using a $1 \%(\mathrm{v} / \mathrm{v})$ inoculum. Strain $\mathrm{EtOH}_{3}{ }^{\mathrm{T}}$ was enriched and isolated using ethanol $(10 \mathrm{mM})$ as the electron donor. The isolation was performed by repeated application of the roll-tube technique (Hungate, 1969) using BM solidified by $20 \mathrm{~g}$ washed agar $1^{-1}$. The purity of cultures was checked by phase-contrast microscopy and by performing growth tests in $B M$ containing yeast extract $\left(1 \mathrm{~g} \mathrm{l}^{-1}\right)$, glucose $(10 \mathrm{mM})$, fumarate $(10 \mathrm{mM})$, pyruvate $(10 \mathrm{mM})$, lactate $(10 \mathrm{mM})$ and succinate $(10 \mathrm{mM})$ at 10 or $100 \mathrm{~g} \mathrm{NaCl}^{-1}$.

Unless stated otherwise, all growth experiments were performed in triplicate in BM dispensed into $16 \times 125 \mathrm{~mm}$ Hungate anaerobic culture tubes (Bellco Glass) with a $3 \mathrm{ml}$ gas phase $\left(90: 10 \mathrm{~N}_{2}: \mathrm{CO}_{2}\right.$, by vol.) using lactate $(10 \mathrm{mM})$ as the electron donor and sulfate as the electron acceptor (lactate subsequently proved to be a better growth substrate than ethanol). Cell growth was quantified by measuring optical density at $600 \mathrm{~nm}$, by phase-contrast microscopy combined with photometric measurement of sulfide by the method of Cline (1969) or, for $\mathrm{pH}$ experiments only, by total counts of SYBR Goldstained cells as described by Mogensen et al. (2005). The effect of temperature on growth rate was investigated simultaneously at 14 different temperatures between 10 and $45^{\circ} \mathrm{C}$ using a temperature gradient block (Elsgaard et al., 1994). The $\mathrm{pH}$ range for growth was investigated by titrating a modified $\mathrm{BM}$ with sterile, anoxic $1 \mathrm{M} \mathrm{HCl}$ or $\mathrm{NaOH}$ solution. This medium, in which $\mathrm{NaHCO}_{3}$ was replaced by $10 \mathrm{~g}$ MOPS $\left(\mathrm{p} K_{\mathrm{a}} 7 \cdot 2\right) 1^{-1}$ and $11 \mathrm{~g}$ CAPSO $\left(\mathrm{p} K_{\mathrm{a}} 9 \cdot 6\right) 1^{-1}$, buffered effectively within a $\mathrm{pH}$ range of $6 \cdot 0-10 \cdot 0$ and did not interfere with the ability of strain $\mathrm{EtOH}^{\mathrm{T}}$ to grow (results not shown). Growth was tested at 11 different $\mathrm{pH}$ values ranging from $6 \cdot 2$ to $9 \cdot 3$; the $\mathrm{pH}$ was monitored regularly during these incubations and adjusted if necessary. Because of the development of precipitates in the modified $\mathrm{BM}$ at $\mathrm{pH}$ values of $>7 \cdot 5$, growth was quantified by total counts of cells stained with SYBR Gold (see above). Strain $\mathrm{EtOH} 3^{\mathrm{T}}$ was tested for growth at 15 different concentrations of $\mathrm{NaCl}$ (ranging from 0 to $300 \mathrm{~g} \mathrm{l}^{-1}$ ) in $\mathrm{BM}$ with and without $0.5 \mathrm{~g}$ yeast extract $\mathrm{l}^{-1}$. Furthermore, the effect of $\mathrm{Mg}^{2+}$ on growth was tested at 21 different concentrations in modified $\mathrm{BM}\left(100 \mathrm{~g} \mathrm{NaCl}^{-1}\right)$ in which $\mathrm{MgSO}_{4} \cdot 7 \mathrm{H}_{2} \mathrm{O}$ was replaced by $\mathrm{Na}_{2} \mathrm{SO}_{4}\left(5 \cdot 76 \mathrm{~g} \mathrm{l}^{-1}\right)$ and $0-200 \mathrm{~g} \mathrm{MgCl}_{2} \cdot 6 \mathrm{H}_{2} \mathrm{O}$ $\mathrm{I}^{-1}$. Substrate utilization was tested by substituting either lactate or sulfate with potential electron donors or electron acceptors (Table 1). Transmission electron microscopy was performed as described previously (Mogensen et al., 2005). The Gram-staining reaction was determined using standard procedures.

Colonies of strain $\mathrm{EtOH}^{\mathrm{T}}$ (in roll-tube cultures) were brown and disc-shaped with a diameter of approximately $1 \mathrm{~mm}$. The cells were oval to rod-shaped and non-motile (transmission electron microscopy did not reveal the presence of flagella; see Supplementary Fig. S1 available in IJSEM Online), often growing in pairs. Cells were $1 \cdot 0-1 \cdot 2 \mu \mathrm{m}$ wide and $2 \cdot 5-3 \cdot 0 \mu \mathrm{m}$ long when grown under optimal conditions (see below). Under suboptimal growth conditions (low salinity, high $\mathrm{pH}$ or high temperature), cells were longer (up to $15 \mu \mathrm{m}$ ) and had a tendency to form filaments. Cells stained Gram-negative and endospores were never observed. When grown on lactate in $\mathrm{BM}$ at $30^{\circ} \mathrm{C}$, the doubling time of strain $\mathrm{EtOH}_{3}{ }^{\mathrm{T}}$ was 2.5 days. Notably, under the same conditions the doubling time increased to $4 \cdot 0$ days when yeast extract $\left(0.5 \mathrm{~g} \mathrm{l}^{-1}\right)$ was omitted from the medium. Strain $\mathrm{EtOH}_{3}{ }^{\mathrm{T}}$ required $\mathrm{NaCl}$ and $\mathrm{Mg}^{2+}$ for growth. Growth occurred in the presence of $\mathrm{NaCl}$ concentrations up to $240 \mathrm{~g} \mathrm{l}^{-1}$ in BM containing $0.5 \mathrm{~g}$ yeast extract $1^{-1}$ and up to $200 \mathrm{~g} \mathrm{l}^{-1}$ in BM devoid of yeast extract. Thus, strain $\mathrm{EtOH}^{\mathrm{T}}$ and Desulfohalobium retbaense, which have identical upper salinity limits for growth (Ollivier et al., 1991), represent the most halotolerant SRB described to date. Optimum growth occurred at $80-100 \mathrm{~g} \mathrm{NaCl}^{-1}$ independent of the presence of yeast extract. This $\mathrm{NaCl}$ optimum classifies strain $\mathrm{EtOH}^{\mathrm{T}}{ }^{\mathrm{T}}$ as a moderate halophile according to Larsen (1986). The highest $\mathrm{MgCl}_{2} \cdot 6 \mathrm{H}_{2} \mathrm{O}$ concentration tolerated by strain $\mathrm{EtOH} 3^{\mathrm{T}}$ was $121 \mathrm{~g} \mathrm{l}^{-1}$, with an optimum ranging from 2 to $51 \mathrm{~g} \mathrm{l}^{-1}$. Despite the high $\mathrm{NaCl}$ tolerance of strain $\mathrm{EtOH} 3^{\mathrm{T}}$ compared with most other known SRB, the observed upper $\mathrm{NaCl}$ limit for growth for this strain nevertheless indicates that it must be challenged by severe salt stress in its natural habitat, i.e. hypersaline sediment of Great Salt Lake, which contained $270 \mathrm{~g} \mathrm{NaCl} \mathrm{l}^{-1}$. The moderately halophilic SRB Desulfovibrio halophilus DSM $5663^{\mathrm{T}}$ was shown previously to profit from the uptake of compatible solutes for osmoadaptation (Welsh et al., 1996). The effect of compatible solutes on the growth of strain $\mathrm{EtOH}_{3}{ }^{\mathrm{T}}$ was tested by adding a mixture consisting of (final concentrations) glycine betaine $(5 \mathrm{mM})$, trehalose $(2.6 \mathrm{mM})$, sucrose $(5 \mathrm{mM})$ and choline $(5 \mathrm{mM})$ to $\mathrm{BM}$ containing $100 \mathrm{~g} \mathrm{NaCl}$ $1^{-1}$ and lactate as the electron donor. The aforementioned test had shown that strain $\mathrm{EtOH}_{3}{ }^{\mathrm{T}}$ was unable to utilize any of these compatible solutes as growth substrates (Table 1). 
Table 1. Phenotypic and genotypic characteristics of strains affiliated to the family Desulfohalobiaceae

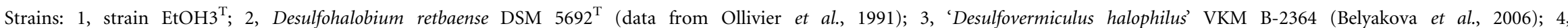

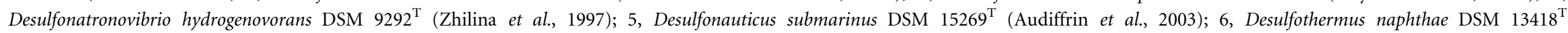

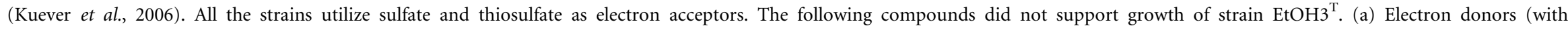

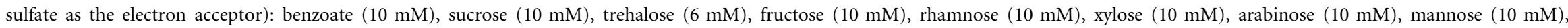

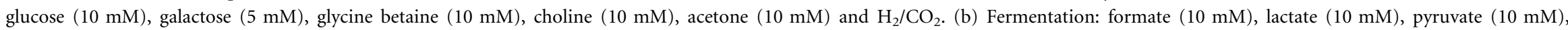

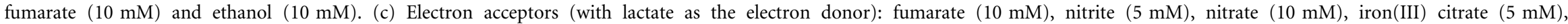
iron(III) chloride $(6 \mathrm{mM})$ and oxygen. NR, Not reported; $(+)$, weak growth.

\begin{tabular}{|c|c|c|c|c|c|c|}
\hline Characteristic & $1^{\star}$ & 2 & 3 & 4 & 5 & 6 \\
\hline Cell shape & Oval-rod-shaped & Curved rod & Curved rod & Vibrio & Curved rod & Curved rod \\
\hline Cell size $(\mu \mathrm{m})$ & $1 \cdot 0-1 \cdot 2 \times 2 \cdot 5-3 \cdot 0(15 \dagger)$ & $0 \cdot 7-0 \cdot 9 \times 1 \cdot 0-3 \cdot 0$ & $0 \cdot 5-0 \cdot 6 \times 1 \cdot 0-15$ & $0 \cdot 5 \times 1 \cdot 5-2 \cdot 0$ & $5 \cdot 0-6 \cdot 0 \times 0 \cdot 35-0 \cdot 5$ & $0 \cdot 8 \times 2 \cdot 0$ \\
\hline Motility & - & + & + & + & + & + \\
\hline $\mathrm{NaCl}$ range (optimum) $\left(\mathrm{g}^{-1}\right)$ & $20-240(80-100)$ & $>0-240(100)$ & $30-230(80-100)$ & $10-120(30)$ & $0-50(20)$ & NR $(20)$ \\
\hline $\mathrm{MgCl}_{2} \cdot 6 \mathrm{H}_{2} \mathrm{O}$ range (optimum) $\left(\mathrm{g} \mathrm{l}^{-1}\right) \ddagger$ & $>0-121(2-51)$ & $>0-142(51)$ & NR (3) & $\mathrm{NR}$ & NR & NR \\
\hline $\mathrm{pH}$ range (optimum) & $6 \cdot 5-8 \cdot 3(6 \cdot 8)$ & $5 \cdot 5-8 \cdot 0(6 \cdot 5-7 \cdot 0)$ & $6 \cdot 0-8 \cdot 5(7 \cdot 2)$ & $8 \cdot 0-10 \cdot 2(9 \cdot 5-9 \cdot 7)$ & NR $(7 \cdot 0)$ & $6 \cdot 1-7 \cdot 1(6 \cdot 5-6 \cdot 8)$ \\
\hline Temperature range (optimum) $\left({ }^{\circ} \mathrm{C}\right)$ & $15-44(37)$ & $25-43(37-40)$ & $25-47(37)$ & $15-43(37)$ & $30-60(45)$ & $50-69(60-65)$ \\
\hline Yeast extract requirement & - & + & - & + & $\mathrm{NR}$ & - \\
\hline $\mathrm{G}+\mathrm{C}$ content of DNA $(\mathrm{mol} \%)$ & $51 \cdot 4$ & $57 \cdot 1$ & $55 \cdot 2$ & $48 \cdot 6$ & $34 \cdot 4$ & 37 \\
\hline \multicolumn{7}{|l|}{ Utilization of electron donors (with sulfate) } \\
\hline $\mathrm{H}_{2} / \mathrm{CO}_{2}$ & - & - & + & - & - & - \\
\hline $\mathrm{H}_{2} /$ acetate & + & + & + & + & + & - \\
\hline Formate & + & + & + & + & + & - \\
\hline Acetate & $-\S$ & - & - & - & - & NR \\
\hline Propionate & + & - & + & - & - & NR \\
\hline Lactate & + & + & + & - & - & - \\
\hline Pyruvate & + & + & + & - & $\mathrm{NR}$ & - \\
\hline Butyrate & + & - & + & - & - & NR \\
\hline Succinate & + & - & + & - & - & - \\
\hline Malate & + & - & + & - & - & - \\
\hline Fumarate & + & - & + & - & - & - \\
\hline Methanol & + & NR & - & - & - & - \\
\hline Ethanol & + & + & + & - & - & - \\
\hline 1-Propanol & + & NR & - & NR & $\mathrm{NR}$ & - \\
\hline 1-Butanol & + & NR & - & NR & NR & - \\
\hline 1-Pentanol & + & NR & NR & NR & $\mathrm{NR}$ & NR \\
\hline Casamino acids & $+(15 \mathrm{mM})$ & - & NR & - & - & - \\
\hline Yeast extract & $+\left(1 \cdot 0 \mathrm{~g} \mathrm{l}^{-1}\right) \|$ & - & - & - & - & - \\
\hline
\end{tabular}




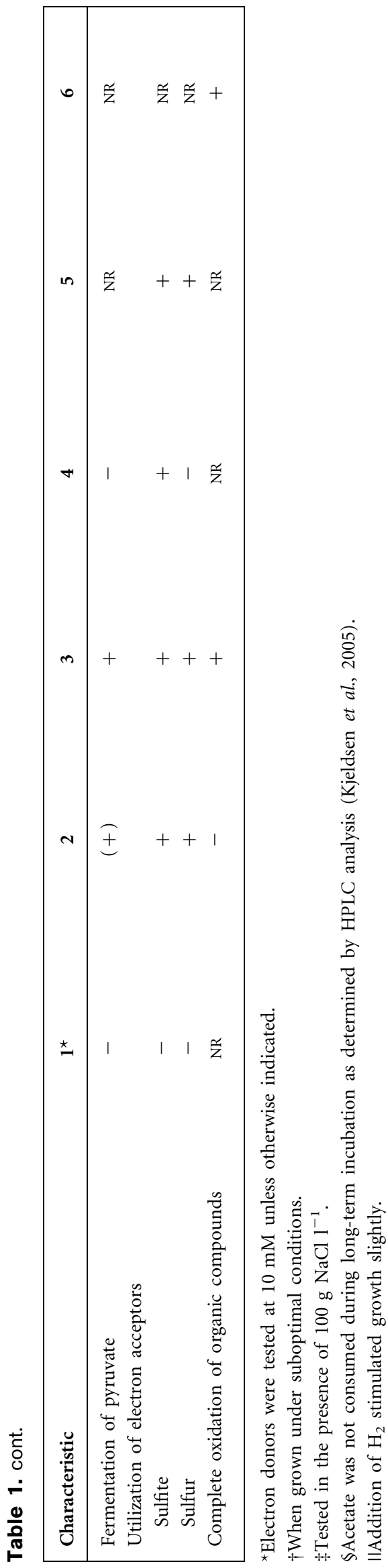

In the presence of yeast extract $\left(0 \cdot 5 \mathrm{~g} \mathrm{l}^{-1}\right)$, the addition of compatible solutes increased the final cell densities and the growth rate of strain $\mathrm{EtOH} 3^{\mathrm{T}}$ by 17 and $13 \%$, respectively. In the absence of yeast extract, the addition of compatible solutes increased the same two values by 22 and $21 \%$, respectively. Each of these increments was significant according to a one-way analysis of variance (results not shown). Although the observed effects were minor, the presence of compatible solutes in the surrounding medium thus seems to enhance the growth of strain $\mathrm{EtOH} 3^{\mathrm{T}}$. In this respect, it is worth mentioning that yeast extract may contain the compatible solute glycine betaine in relatively large amounts (Galinski \& Trüper, 1994) in addition to other possible growth-stimulating compounds. The availability of the tested or other more potent osmolytes in the Great Salt Lake sediment may help to explain the abovementioned discrepancy between the $\mathrm{NaCl}$ tolerance of strain $\mathrm{EtOH} 3^{\mathrm{T}}$ in vitro and the salinity of the sediment in situ. The optimum $\mathrm{pH}$ for growth of strain $\mathrm{EtOH} 3^{\mathrm{T}}$ was $6 \cdot 8$ and growth was detected between $\mathrm{pH} 6 \cdot 5$ and $8 \cdot 3$. The strain was mesophilic, growing within a temperature range of $15 \cdot 0-43 \cdot 6^{\circ} \mathrm{C}$ with an optimum at $37^{\circ} \mathrm{C}$. Unlike other members of the family Desulfohalobiaceae, and other halophilic SRB, strain $\mathrm{EtOH}^{\mathrm{T}}{ }^{\text {utilized a broad range of }}$ different electron donors (Table 1). For instance, strain $\mathrm{EtOH} 33^{\mathrm{T}}$ grew on propionate, methanol and Casamino acids, which, respectively, are only utilized by the weakly to moderately halophilic SRB Desulfacinum hydrothermale DSM $13146^{\mathrm{T}}$ (Sievert \& Kuever, 2000), as well as 'Desulfovermiculus halophilus' (Belyakova et al., 2006), 'Desulfovibrio cavernae' H1M (Sass \& Cypionka, 2004) and 'Desulfovibrio brasiliensis' DSM 15816 (Warthmann et al., 2005). In contrast to other members of the family Desulfohalobiaceae, strain $\mathrm{EtOH}^{\mathrm{T}}$ was unable to use sulfite as a terminal electron acceptor (Table 1). This finding was unexpected, as the strain harboured genes $(d s r A B)$ encoding the alpha and beta subunits of the dissimilatory (bi)sulfite reductase enzyme (EC number 1.8.99.3) (Fig. 1b). It may be argued that the concentrations of sulfite tested $(2.5$ and $5.0 \mathrm{mM}$ ) were toxic to strain EtOH3 $3^{\mathrm{T}}$. However, the strain was able to grow when the same concentrations of sulfite were added to BM containing sulfate and, furthermore, sulfite had no effect on the morphology of the cells as evaluated by phase-contrast microscopy (results not shown). These findings indicated that the sulfite concentrations applied were not toxic to strain $\mathrm{EtOH} 3^{\mathrm{T}}$. It is therefore possible that the strain lacks a transport mechanism for the uptake of sulfite.

The $d s r A B$ and $16 \mathrm{~S}$ rRNA gene sequences of strain $\mathrm{ETOH} 3^{\mathrm{T}}$ were retrieved, aligned and compiled as described previously (Abildgaard et al., 2006). Phylogenetic 16S rRNA gene sequence-based trees were inferred from neighbour-joining (with Jukes-Cantor distance correction), maximumparsimony and maximum-likelihood analyses of a sequence dataset consisting of sequences of $>1300 \mathrm{nt}$ and including a broad range of proteobacterial taxa. Analyses were performed using the respective algorithms of the ARB program 
(a)

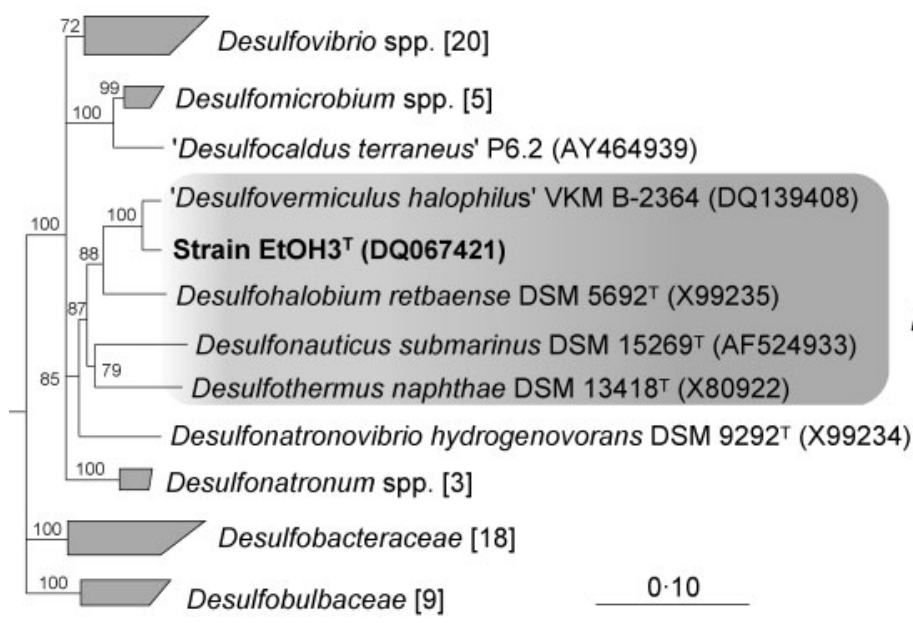

(b)

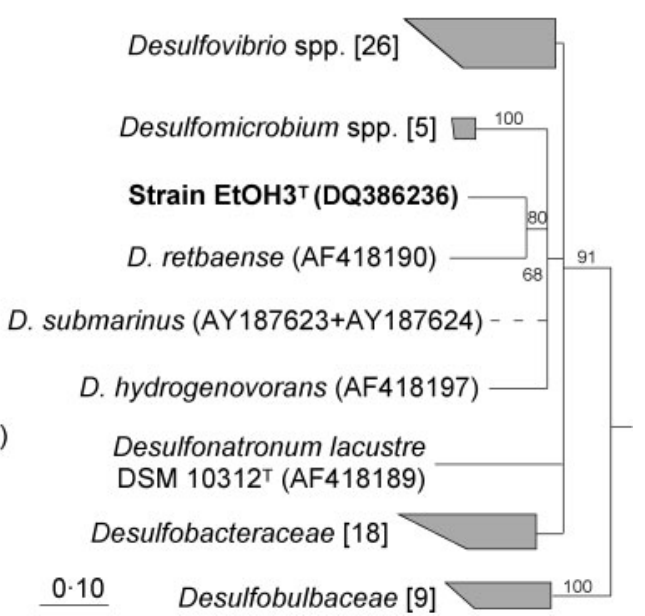

Fig. 1. Consensus trees based on comparative analyses of 16S rRNA gene (a) and DsrAB amino acid sequences (b) showing the inferred phylogenetic position of strain $\mathrm{EtOH}^{\top}$ among members of the class Deltaproteobacteria. Numbers at nodes indicate neighbour-joining (16S rRNA) or distance-matrix (DsrAB)-based bootstrap values (100 replications). 16S rRNA gene sequence taxa affiliated with the family Desulfohalobiaceae are shaded. Broken lines indicate partial sequences subsequently added to the trees without changing their overall topology using parsimony criteria. Numbers in square brackets indicate the number of taxa contained in the respective groupings. Bars, $10 \%$ sequence divergence as estimated by neighbour-joining (16S rRNA) and distance-matrix (DsrAB) analysis. Details of the construction of the trees are given in the text.

package (Ludwig et al., 2004). Two different filters [the deltaproteobacterial $50 \%$ conservation filter of the ssu_jan04_corr_opt ARB database (available at http://www. arb-home.de) and a custom-made $50 \%$ conservation filter calculated for the Desulfohalobiaceae-affiliated taxa shown in Fig. 1a] were used to select sequence positions for the analyses. Neighbour-joining-based bootstrap analysis was performed in PAUP*, version 4.0b10 (Swofford, 2003). Phylogenetic analyses of DsrAB amino acid sequence (deduced from nucleotide sequences) datasets including 530 unambiguously aligned positions were performed as described previously (Abildgaard et al., 2006). The phylogenetic consensus trees shown in Fig. 1 were constructed as recommended by Ludwig et al. (1998). A range of outgroup taxa were removed from the presented phylogenetic consensus trees; complete trees are available from the corresponding author on request. The genomic $\mathrm{G}+\mathrm{C}$ content of strain $\mathrm{EtOH}_{3}{ }^{\mathrm{T}}$ was determined by HPLC analysis at the Identification Service of DSMZ (Deutsche Sammlung von Mikroorganismen und Zellkulturen GmbH, Braunschweig, Germany).

Phylogenetic analyses of the $d s r A B$ and 16S rRNA gene sequences of strain $\mathrm{EtOH}_{3}{ }^{\mathrm{T}}$ consistently grouped the strain within the deltaproteobacterial family Desulfohalobiaceae (Fig. 1). The phylogenetically closest relative of strain $\mathrm{EtOH}^{\mathrm{T}}$ with a validly published name was Desulfohalobium retbaense (Ollivier et al., 1991), sharing 76.0 and $90 \cdot 5 \% d s r A B$ and $16 \mathrm{~S}$ rRNA gene sequence similarity, respectively, with strain $\mathrm{EtOH}_{3}^{\mathrm{T}}$ (Fig. 1). Recently the isolation of a novel moderately halophilic SRB, 'Desulfovermiculus halophilus' strain 11, was reported (Belyakova et al., 2006). No $d s r A B$ data are currently available for 'Desulfovermiculus halophilus' strain 11, but the 16S rRNA gene sequence of this strain differs by only $3 \cdot 1 \%$ (1413 nt included) from that of strain $\mathrm{EtOH}^{\mathrm{T}}{ }^{\mathrm{T}}$ (Fig. 1a). The $16 \mathrm{~S}$ rRNA gene sequence of strain $\mathrm{EtOH}^{\mathrm{T}}$ contained a unique $97 \mathrm{nt}$ insert from positions 186 to 191 (Escherichia coli numbering), which is absent in the 16S rRNA gene sequences of all other species affiliated with the family Desulfohalobiaceae. This region was not included in phylogenetic analyses. The DNA of strain $\mathrm{EtOH}^{\mathrm{T}}$ differed in $\mathrm{G}+\mathrm{C}$ content by $5 \cdot 7$ and $3 \cdot 8 \mathrm{~mol} \%$ from Desulfohalobium retbaense and 'Desulfovermiculus halophilus', respectively (Table 1). This is around the threshold of $5 \mathrm{~mol} \%$ difference in genomic $\mathrm{G}+\mathrm{C}$ content empirically observed generally to constitute the common range within a species (RossellóMora \& Amann, 2001). In contrast to the comparison of the available genotypic data, strain $\mathrm{EtOH}^{\mathrm{T}}$ differed significantly from 'Desulfovermiculus halophilus' when comparing their phenotypic characteristics (Table 1). Most notably, 'Desulfovermiculus halophilus' differed from strain $\mathrm{EtOH}^{\mathrm{T}}$ in its capacity for autotrophic growth, its low $\mathrm{Mg}^{2+}$ tolerance and its limited ability to grow using alcohols (Table 1). Similarly, several phenotypic characteristics differentiated strain $\mathrm{EtOH}^{\mathrm{T}}$ from Desulfohalobium retbaense as well as the other species affiliated with the family Desulfohalobiaceae (Table 1). The cellular fatty acid profile 
of strain $\mathrm{EtOH} 3^{\mathrm{T}}$ was determined at the Identification Service of the DSMZ. Cells used for the analysis were cultivated in $\mathrm{BM}$ containing $100 \mathrm{~g} \mathrm{NaCl} \mathrm{l}^{-1}$ and $10 \mathrm{mM}$ lactate, harvested by centrifugation $(16000 \mathrm{~g})$, washed with $20 \mathrm{~g} \mathrm{NaCl} \mathrm{l}^{-1}$ solution and freeze-dried. The major fatty acids of strain $\mathrm{EtOH} 3^{\mathrm{T}}$ were (calculation method TSBA50): iso- $\mathrm{C}_{15: 0}(68 \cdot 47 \%)$, iso- $\mathrm{C}_{17: 0}(11 \cdot 61 \%)$, iso- $\mathrm{C}_{17: 1} \omega 9 c$ $(5 \cdot 92 \%)$, iso- $\mathrm{C}_{15: 0} 3-\mathrm{OH}(3 \cdot 19 \%), \mathrm{C}_{16: 0}(2 \cdot 15 \%), \mathrm{C}_{18: 0}$ (2.98\%), 10-methyl $\mathrm{C}_{18: 0}$ (tuberculostearic acid) $(1 \cdot 15 \%)$, iso- $\mathrm{C}_{17: 0} 3-\mathrm{OH}(0.89 \%)$ and iso- $\mathrm{C}_{16: 0}(0.79 \%)$. No substantial similarities in the fatty acid profiles of strain $\mathrm{EtOH}_{3}{ }^{\mathrm{T}}$ and Desulfohalobium retbaense (Ollivier et al., 1991) were evident. Unfortunately, fatty acid profiles have not been published for 'Desulfovermiculus halophilus'.

Several physiological characteristics of Desulfohalobium retbaense, 'Desulfovermiculus halophilus' and strain $\mathrm{EtOH}_{3}{ }^{\mathrm{T}}$, such as the $\mathrm{NaCl}$, temperature and $\mathrm{pH}$ ranges for growth, were very similar (Table 1). This is in agreement with their strong phylogenetic coherence demonstrated by the $d s r A B$ and $16 \mathrm{~S}$ rRNA gene sequence analyses (Fig. 1). Based on the phenotypic and genotypic data discussed above, it is proposed that strain $\mathrm{EtOH} 3^{\mathrm{T}}$ represents a novel species within the genus Desulfohalobium, Desulfohalobium utahense sp. nov. As the name 'Desulfovermiculus halophilus' has not yet been validly published, strain $\mathrm{EtOH} 3^{\mathrm{T}}$ cannot be assigned to its genus, although this might seem justifiable from the available phylogenetic data avoiding making the genus Desulfohalobium paraphyletic (Fig. 1a). In fact, according to its genotypic and phenotypic characteristics (Fig. 1a; Table 1), it may even be warranted to reclassify 'Desulfovermiculus halophilus' as a novel member of the genus Desulfohalobium. Future research resulting in the description of additional members of the family Desulfohalobiaceae and in particular the genus Desulfohalobium will allow this issue to be addressed in further detail.

\section{Description of Desulfohalobium utahense sp. nov.}

Desulfohalobium utahense (u'tah.en'se. N.L. neut. adj. utahense pertaining to the state of Utah, USA, where the type strain was first isolated).

Cells are non-motile, oval to rod-shaped $(1 \cdot 0-1 \cdot 2 \times$ $2 \cdot 5-3 \cdot 0 \mu \mathrm{m})$ and occur singly or in pairs. Under suboptimal conditions, cell elongation (up to $15 \mu \mathrm{m}$ ) and/or filamentous growth may occur. Cells stain Gram-negative and do not contain endospores. Anaerobic and chemo-organotrophic. Utilizes (with sulfate as the electron acceptor): formate, propionate, lactate, pyruvate, butyrate, succinate, malate, fumarate, methanol, ethanol, 1-propanol, 1-butanol, 1-pentanol, yeast extract, Casamino acids, $\mathrm{H}_{2}$ /acetate and $\mathrm{H}_{2}$ /yeast extract. Acetate is not oxidized during longterm incubation. Sulfate and thiosulfate are used as electron acceptors with lactate as the electron donor. Sulfur and sulfite are not reduced. Yeast extract improves, but is not required for, growth. Temperature range is $15 \cdot 0-43 \cdot 6^{\circ} \mathrm{C}$ with an optimum of $37^{\circ} \mathrm{C}$. Sodium and magnesium ions are required for growth, the $\mathrm{NaCl}$ and $\mathrm{MgCl}_{2} \cdot 6 \mathrm{H}_{2} \mathrm{O}$ growth ranges being $20-240$ and $>0-121 \mathrm{~g}^{-1}$, respectively. The optimum $\mathrm{NaCl}$ and $\mathrm{MgCl}_{2} \cdot 6 \mathrm{H}_{2} \mathrm{O}$ concentrations are $80-100$ and $2-51 \mathrm{~g} \mathrm{l}^{-1}$, respectively. The optimum $\mathrm{pH}$ is $6 \cdot 8-7 \cdot 5$. Growth occurs between $\mathrm{pH} 6 \cdot 5$ and $8 \cdot 3$. The $\mathrm{G}+\mathrm{C}$ content of the DNA is $51 \cdot 4 \mathrm{~mol} \%$.

The type strain, EtOH3 $3^{\mathrm{T}}\left(=\mathrm{VKM} \mathrm{B}-2384^{\mathrm{T}}=\mathrm{DSM} 17720^{\mathrm{T}}\right)$, was isolated from the hypersaline northern arm of Great Salt Lake, Utah, USA.

\section{Acknowledgements}

The authors thank Tove Wiegers, Pernille V. Thykier and Britta Poulsen for excellent technical assistance.

\section{References}

Abildgaard, L., Nielsen, M. B., Kjeldsen, K. U. \& Ingvorsen, K. (2006). Desulfovibrio alkalitolerans sp. nov., a novel alkalitolerant, sulphate-reducing bacterium isolated from district heating water. Int J Syst Evol Microbiol 56, 1019-1024.

Audiffrin, C., Cayol, J.-L., Joulian, C., Casalot, L., Thomas, P., Garcia, J.-L. \& Ollivier, B. (2003). Desulfonauticus submarinus gen. nov., sp. nov., a novel sulphate-reducing bacterium isolated from a deep-sea hydrothermal vent. Int J Syst Evol Microbiol 53, 1585-1590.

Belyakova, E. V., Rozanova, E. P., Borzenkov, I. A., Tourova, T. P., Pusheva, M. A., Lysenko, A. M. \& Kolganova, T. V. (2006). The new facultatively chemolithoautotrophic, moderately halophilic, sulfatereducing bacterium Desulfovermiculus halophilus gen. nov., sp. nov., isolated from an oil field. Microbiology (English translation of Mikrobiologiia) 75, 161-171.

Brandt, K. K. \& Ingvorsen, K. (1997). Desulfobacter halotolerans sp. nov., a halotolerant acetate-oxidizing sulfate-reducing bacterium isolated from sediments of Great Salt Lake, Utah. Syst Appl Microbiol 20, 366-373.

Brandt, K. K., Vester, F., Jensen, A. N. \& Ingvorsen, K. (2001). Sulfate reduction dynamics and enumeration of sulfate-reducing bacteria in hypersaline sediments of the Great Salt Lake (Utah, USA). Microb Ecol 41, 1-11.

Cline, J. D. (1969). Spectrophotometric determination of hydrogen sulfide in natural waters. Limnol Oceanogr 14, 454-458.

Elsgaard, L., Isaksen, M. F., Jørgensen, B. B., Alayse, A.-M. \& Jannasch, H. W. (1994). Microbial sulfate reduction in deepsea sediments at the Guaymas Basin hydrothermal vent area: influence of temperature and substrates. Geochim Cosmochim Acta 58, 3335-3343.

Galinski, E. A. \& Trüper, H. G. (1994). Microbial behavior in saltstressed ecosystems. FEMS Microbiol Rev 15, 95-108.

Hungate, R. E. (1969). A roll tube method for cultivation of strict anaerobes. Methods Microbiol 3B, 117-132.

Kjeldsen, K. U., Joulian, C. \& Ingvorsen, K. (2005). Effects of oxygen exposure on respiratory activities of Desulfovibrio desulfuricans strain DvO1 isolated from activated sludge. FEMS Microbiol Ecol 53, 275-284

Krekeler, D., Sigalevich, P., Teske, A., Cypionka, H. \& Cohen, Y. (1997). A sulfate-reducing bacterium from the oxic layer of a microbial mat from Solar Lake (Sinai), Desulfovibrio oxyclinae sp. nov. Arch Microbiol 167, 369-375.

Kuever, J., Rainey, F. A. \& Widdel, F. (2005). Family III. Desulfohalobiaceae fam. nov. In Bergey's Manual of Systematic 
Bacteriology, 2nd edn, vol. 2 (The Proteobacteria), part C (The Alpha-, Beta-, Delta-, and Epsilonproteobacteria), pp. 948-952. Edited by D. J. Brenner, N. R. Krieg, J. T. Staley \& G. M. Garrity. New York: Springer.

Kuever, J., Rainey, F. A. \& Widdel, F. (2006). Desulfothermus gen. nov. In List of New Names and Combinations Previously Effectively, but not Validly, Published, Validation List no. 107. Int J Syst Evol Microbiol 56, 1-6.

Larsen, H. (1986). Halophilic and halotolerant microorganisms: an overview and historical perspective. FEMS Microbiol Rev 39, 3-7.

Ludwig, W., Strunk, O., Klugbauer, S., Klugbauer, N., Weizenegger, M., Neumaier, J., Bachleitner, M. \& Schleifer, K.-H. (1998). Bacterial phylogeny based on comparative sequence analysis. Electrophoresis 19, 554-568.

Ludwig, W., Strunk, O., Westram, R. \& 26 other authors (2004). ARB: a software environment for sequence data. Nucleic Acids Res 32, 1363-1371.

Mogensen, G. L., Kjeldsen, K. U. \& Ingvorsen, K. (2005). Desulfovibrio aerotolerans sp. nov., an oxygen tolerant sulfate-reducing bacterium isolated from activated sludge. Anaerobe 11, 339-349.

Ollivier, B., Hatchikian, C. E., Prensier, G., Guezennec, J. \& Garcia, J.-L. (1991). Desulfohalobium retbaense gen. nov., sp. nov., a halophilic sulfate-reducing bacterium from sediments of a hypersaline lake in Senegal. Int J Syst Bacteriol 41, 74-81.

Rosselló-Mora, R. \& Amann, R. (2001). The species concept for prokaryotes. FEMS Microbiol Rev 25, 39-67.
Sass, H. \& Cypionka, H. (2004). Isolation of sulfate-reducing bacteria from the terrestrial deep subsurface and description of Desulfovibrio cavernae sp. nov. Syst Appl Microbiol 27, 541-548.

Sievert, S. M. \& Kuever, J. (2000). Desulfacinum hydrothermale sp. nov., a thermophilic, sulfate-reducing bacterium from geothermally heated sediments near Milos Island (Greece). Int J Syst Evol Microbiol 50, 1239-1246.

Swofford, D. L. (2003). PAUP* ${ }^{*}$ phylogenetic analysis using parsimony ( ${ }^{*}$ and other methods), version 4.0b10. Sunderland, MA: Sinauer Associates.

Warthmann, R., Vasconcelos, C., Sass, H. \& McKenzie, J. A. (2005). Desulfovibrio brasiliensis sp. nov., a moderate halophilic sulfatereducing bacterium from Lagola Vermelha (Brazil) mediating dolomite formation. Extremophiles 9, 255-261.

Welsh, D. T., Lindsay, Y. E., Caumette, P., Herbert, R. A. \& Hannan, J. (1996). Identification of trehalose and glycine betaine as compatible solutes in the moderately halophilic sulfate reducing bacterium, Desulfovibrio halophilus. FEMS Microbiol Lett 140, 203-207.

Widdel, F. \& Bak, F. (1992). Gram-negative mesophilic sulfatereducing bacteria. In The Prokaryotes, 2nd edn, pp. 3352-3378. Edited by A. Balows, H. G. Trüper, M. Dworkin, W. Harder \& K. H. Schleifer. New York: Springer.

Zhilina, T. N., Zavarzin, G. A., Rainey, F. A., Pikuta, E. N., Osipov, G. A. \& Kostrikina, N. A. (1997). Desulfonatronovibrio hydrogenovorans gen. nov., sp. nov., an alkaliphilic, sulfate-reducing bacterium. Int J Syst Bacteriol 47, 144-149. 